\title{
ANALYSIS OF WORKING PERFORMANCE IN ENGINEERING MODIFICATION OF FEROZA VEHICLES WITH FUEL INJECTION SYSTEM
}

\author{
Apriyanto ${ }^{1}$, Moch. Ma' ruf $^{2^{*}}$, Tuharno ${ }^{1}$ \\ ${ }^{1}$ Department of IFV, Poltekad, Malang \\ ${ }^{2}$ Department of Mechanical Engineering, Faculty of Engineering, University of Merdeka Malang \\ *Email corresponding author: moch.maruf@unmer.ac.id
}

\begin{abstract}
Daihatsu Feroza vehicle is one type of official vehicle that is still used to support basic tasks in the ranks of the Army. This vehicle is one of the vehicles that wasteful of fuel. This is influenced by the fuel system used is the conventional fuel system. To overcome this, modifications are made to the fuel system of the feroza service vehicles using a fuel injection system that is more fuel efficient. Testing using the fuel injection system has decreased compared to by using a conventional fuel system at engine power and engine thermal efficiency. From the analysis it was concluded that the effective power and efficiency of the engine produced using the injection system is smaller than using conventional systems. Power at $1800 \mathrm{rpm}$ engine speed uses an injection system that is $210 \mathrm{Nm}$ with a thermal efficiency of $42.97 \%$ and uses a conventional system that is $240 \mathrm{Nm}$ with a thermal efficiency of $48.20 \%$.
\end{abstract}

Keywords: Engine Modification, Machine Performance, Conventional System \& Injection System

\section{INTRODUCTION}

Current technological advances, especially in the military world, have resulted in the use of vehicles as the mobility of troops even higher to compensate for the need for everything that supports these technological advances. High troop mobility will certainly require better vehicles with reliable, comfortable, safe and good quality performance.

The Feroza vehicle is one type of official vehicle owned by the Army in supporting its main duties in the ranks of the Army. However, this vehicle is an old vehicle that uses conventional technology with a low level of thermal efficiency. Therefore it is necessary to modify the Feroza official vehicles by using the Multi Point Fuel Injection System which is expected to increase engine performance and better thermal efficiency.

Based on the description above, the author will apply it in the form of a final project entitled "Analysis of Working

Performance in Engineering Modification of Feroza Vehicles with Fuel Injection System" so that by analyzing the Feroza official vehicles that have been modified with the injection system, it can be seen that the increase in performance and thermal efficiency of the Feroza official vehicles.

\section{Research Question}

To clarify the scope of the problems discussed, it is necessary to have limitations, including:

a. The engine used for modification is the Daihatsu Feroza HD-C engine with a cylinder capacity of $1589 \mathrm{cc}$.

b. The fuel injection system used for modification is the 1NZ-FE type.

\section{Research Limitation}

In this article the author only discusses the performance of the Daihatsu Feroza engine using the Fuel Injection System. 


\section{Research Objection}

Referring to the problems above, the objectives to be achieved in the preparation of this article are:

a. As a learning about combustion motor.

b. Knowing the performance of machines with conventional systems and injection systems.

c. Knowing the efficiency of the Feroza Service vehicles with the Fuel Injection System.

\section{LITERATURE REVIEW}

\section{Motor Fuel}

In general, the internal combustion engine (Internal Combustion Engine) is known as the combustion motor. The combustion process takes place in the combustion motor itself, so that the combustion gas that occurs simultaneously functions as a working fluid. Motor combustion, in its work using a piston which can work in translation (back and forth) in the cylinder. Because it is in the cylinder that combustion occurs between fuel and air and produces combustion gas which is able to move the piston which is connected to the crankshaft through the connecting rod. Here the translational motion is converted into a rotational motion.

\section{Gasoline Engine Fuel System}

In a gasoline engine, the air and fuel are mixed before entering the combustion chamber with the fuel injection in the carburetor which utilizes the vacuum in the combustion chamber, this fuel system is called a conventional fuel system. At present, almost all gasoline engine products apply fuel injection to the intake manifold before entering the combustion chamber cylinder to obtain environmentally friendly exhaust emissions. The fuel injection system in the Otto motor occurs outside the cylinder, its purpose is to mix air with fuel perfectly. This is called EFI (Electronic Fuel Injection). The mixing of air and fuel is carried out by a carburetor or injection system, both of which have evolved from a manual system to the addition of electronic sensors.

\section{Carburetor Fuel System}

In the carburetor fuel system, all components work more mechanically, but there are also a few components that work electronically. The components of the carburetor fuel system are as follows:

1. Fuel Tank.

2. Fuel pumps.

3. Fuel filter.

4. Carburetor.

\section{Injection Fuel System}

Fuel injection is a technology used in internal combustion engines to mix fuel with air before it is burned. The use of fuel injection will increase engine power when compared to using a carburetor, because the injector makes the fuel mix homogeneously.

The way the MPI (Mitsubishi) system works is the same as EFI (Toyota). Where the amount of fuel sprayed into the combustion chamber will be adjusted to the needs of the 
engine, when the engine is stationary, the fuel flow is less than at high speed and is different when the vehicle is uphill and there is a load. All of that is regulated based on sensor information, including: water intake temperature sensor, barometric pressure sensor, vehicle speed sensor, oxygen sensor etc. This data is sent to the ECU (Electronic Control Unit) and will instruct the actuators, one of which is the fuel injector. If there is a problem with a sensor, the ECU will automatically stabilize the engine speed so that the engine is not disturbed, but later there will be an indicator on the dashboard that will turn on to tell the driver to immediately check the vehicle.

\section{Multi-Point Injection System components}

In supporting the work of the fuel system, several components are needed so that the fuel system can work properly. The components of the MPI fuel system with ECU are as follows:

a. Fuel pumps.

b. Fuel tank.

c. Gasoline Pressure Regulator.

d. Injector.

e. ECU.

f. Fuel hose.

g. Sensors.
Specifications and Characteristics of Daihatsu Feroza Vehicle Engines

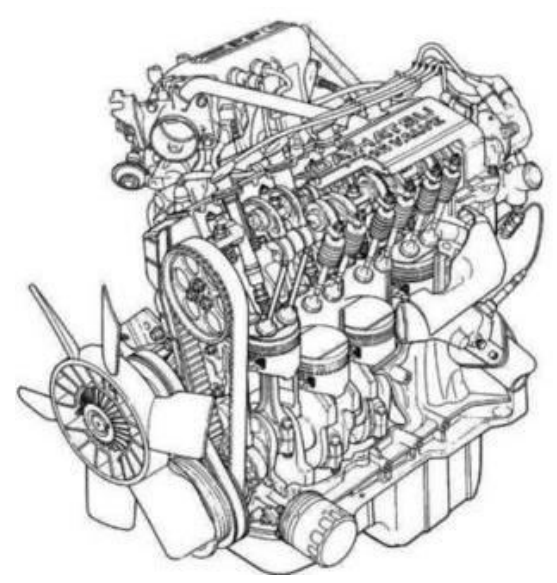

Figure 1. Daihatsu Feroza engine. (Source: Manual book of daihatsu Feroza) The following is the data table of the Daihatsu Feroza specifications:

\section{DAIHATSU FEROZA}

\section{ENGINE}
Type : HD-C, gasoline, water cooled

$\begin{array}{ll}\text { Cylinder capacity } & : 1589 \mathrm{cc} \\ \text { Total cylinder } & : 4 \text { in line }\end{array}$

Total valve $\quad: 16$, SOHC

Diameter $\mathrm{x}$ step $\quad: 76,0 \times 87,6 \mathrm{~mm}$

Comparison of $\quad: 9,5: 1$ compression

Maximum power $\quad$ : 85,7 PS/6000 rpm

Maximum torque $\quad: 12,9 \mathrm{kgm} / 3600 \mathrm{rpm}$

Tabel 1. Daihatsu Feroza specifications. (Source: Manual book of Daihatsu feroza) 


\section{Comparison of the Fuel Air Mixture in the Carburetor with the Injection System}

a. Carburetor system

The mixture of air and fuel is fed into the cylinder through 2 channels, namely the low speed channel when the engine is stationary and the high speed channel when the engine is running at high speed. The fuel in the tank has the same pressure as the outside air pressure, which is 1 atm or $1 \mathrm{bar}$, while the pressure on the intake manifold is -1 bar so that the difference in pressure is 2 bar and for fogging the fuel is still not perfect because the greater the pressure difference between the fuel pressures With the pressure in the intake manifold, the better for mixing air and fuel in the combustion chamber.

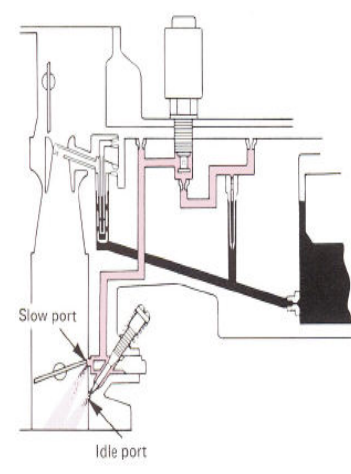

LOW.SPEED OPERATING RANGE

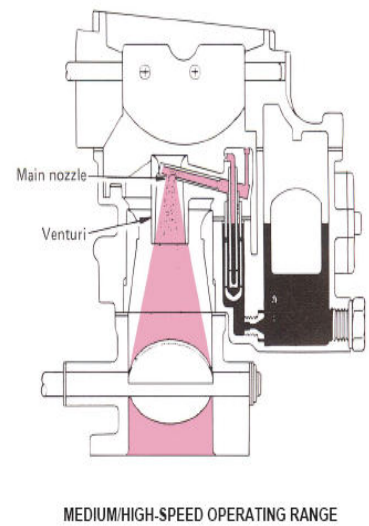

MEDIUMHIGH-SPEED OPERATING RANGE
Figure 2. Mixing Air and Fuel in the Carburetor

(Source: Astra International Daihatsu)

b. Injection Sytem

The fuel injection system is pressurized so that when it enters the intake manifold the fuel has a pressure of 3 bar while the pressure in the intake manifold is -1 bar so that there is a difference of 4 bars which causes better fuel fog because the high pressure causes particles from the fuel becomes very small and flammable.

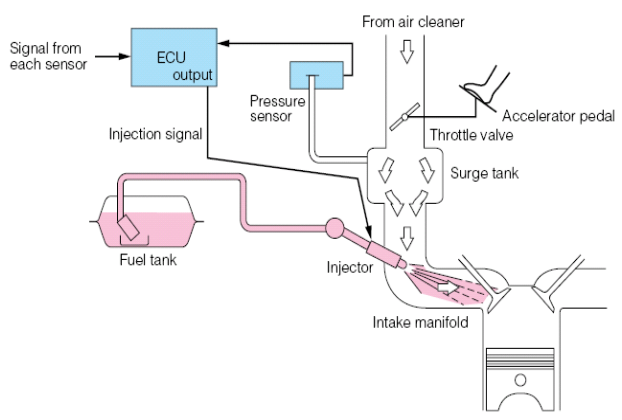

Figure 3. Injection System.

(Source: Astra International Daihatsu)

c. The advantages of EFI compared to carburetors are as follows:

1) Allows the formation of a homogeneous mixture in each cylinder.

a) One cylinder one injector.

b) The fuel injection volume is controlled by the ECU in accordance with the rpm and engine load.

2) Accurate air and fuel comparison.

a) Delivery of the air and fuel mixture is continuous according to speed and load.

b) Stokiometry occurs, namely the ratio of moles of air and moles of fuel so that complete combustion occurs.

\section{METHODOLOGY OF RESEARCH}

In this research method aims to analyze the performance of engine modification Daihatsu Feroza Service Vehicle with injection system. 


\section{Time and Place of Research}

In the implementation of this final project, the implementation is divided into several writing stages starting from observing functions, working methods, collecting data, and testing to determine the performance of the Daihatsu Feroza Service Vehicle modification engine with this injection system.

1. Place Testing tools. Testing of this tool is carried out at the VEDC Engineering workshop, Malang.

2. Execution time. Testing of this tool starts from April 2018.

\section{Research Flowchart}

To facilitate the implementation of the analysis, a research methodology flow chart block design is needed, for the flow chart it can be shown in Figure 4 below:

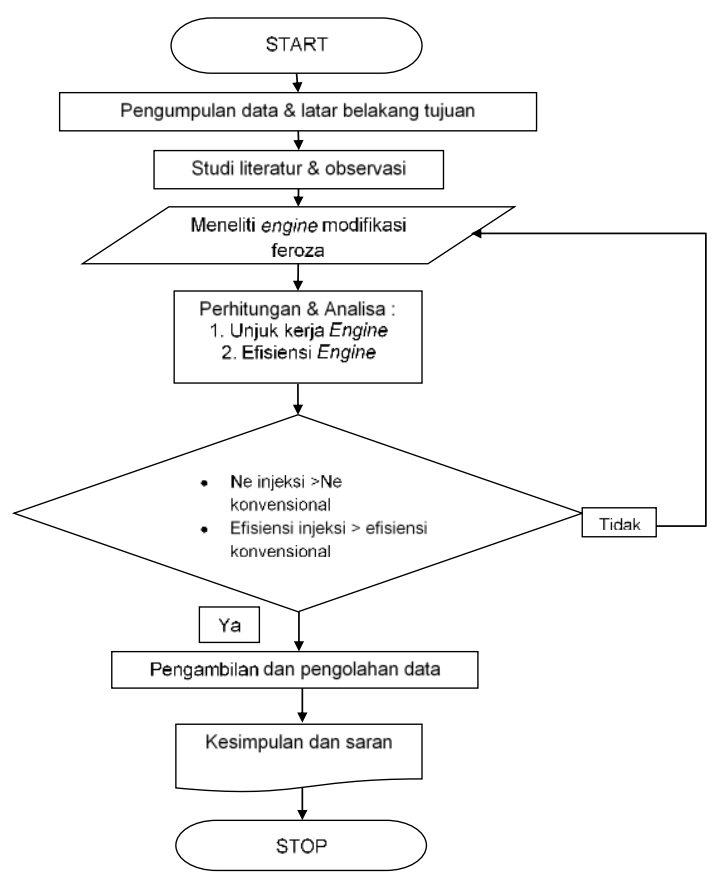

Figure 4. Research Flowchart

\section{Planned Variable}

There are two variables used in this study, namely the independent and dependent variables as below:
1. The independent variable is the variable whose magnitude is determined by the author, namely engine speed.

2. The dependent variable is a variable whose magnitude cannot be determined by the author, but the amount depends on the independent variable. In this plan the dependent variable is as follows:

a. Engine power.

b. Engine efficiency.

\section{Data Retrieval Tool}

In this research procedure, before taking engine power data, it is necessary to prepare supporting tools and materials in the data collection process. In the data collection process, data was collected twice. The first data collection is carried out when the vehicle is still using the engine with a conventional system. The vehicle is positioned on the dyno test instrument, then the vehicle is tied for safety factors and the fan placed in front of the vehicle is used as a coolant from the engine which is thought to be the air that cools the engine when the vehicle is being driven. The data obtained after testing include torque and power. The second test was carried out in the same way and with the same tool. In the second test the engine used on the Feroza vehicle had been replaced by using the fuel injection system. 


\section{RESULT}

In analyzing a machine with a conventional and fuel injection system, it is necessary to do calculations that are supported by the appropriate theory. In this calculation, the emphasis is on the power and efficiency of the engine so that the tool can function properly.

\section{Results of Data Retrieval}

The Daihatsu Feroza engine performance table is as follows:

Table 2. The results of data retrieval engine Daihatsu Feroza with conventional systems.

\begin{tabular}{|c|c|c|}
\hline No & $\begin{array}{c}\text { Rotation (n) } \\
(\mathrm{rpm})\end{array}$ & $\begin{array}{c}\text { Torque (T) } \\
(\mathrm{Nm})\end{array}$ \\
\hline 1 & 1800 & 240 \\
\hline 2 & 2000 & 248 \\
\hline 3 & 2200 & 258 \\
\hline 4 & 2400 & 260 \\
\hline 5 & 2600 & 262 \\
\hline 6 & 2800 & 265 \\
\hline 7 & 3000 & 269 \\
\hline 8 & 3200 & 272 \\
\hline 9 & 3400 & 272 \\
\hline 10 & 3600 & 267 \\
\hline 11 & 3800 & 270 \\
\hline 12 & 4000 & 261 \\
\hline 13 & 4200 & 254 \\
\hline 14 & 4400 & 246 \\
\hline
\end{tabular}

Table 3. The results of data retrieval engine Daihatsu Feroza with injection system.

\begin{tabular}{|c|c|c|}
\hline No & $\begin{array}{c}\text { Rotation (n) } \\
(\mathrm{rpm})\end{array}$ & $\begin{array}{c}\text { Torque (T) } \\
(\mathrm{Nm})\end{array}$ \\
\hline 1 & 1800 & 210 \\
\hline 2 & 2000 & 215 \\
\hline 3 & 2200 & 228 \\
\hline 4 & 2400 & 244 \\
\hline 5 & 2600 & 238 \\
\hline 6 & 2800 & 222 \\
\hline 7 & 3000 & 225 \\
\hline 8 & 3200 & 224 \\
\hline 9 & 3400 & 219 \\
\hline 10 & 3600 & 218 \\
\hline 11 & 3800 & 219 \\
\hline 12 & 4000 & 220 \\
\hline 13 & 4200 & 228 \\
\hline 14 & 4400 & 229 \\
\hline
\end{tabular}

\section{Calculate Calculation Data}

a. Torque

$$
\begin{aligned}
& T=F \times r(\mathrm{Nm}) \\
& T=210 \mathrm{Nm}
\end{aligned}
$$

b. Effective Power (Ne).

$$
\begin{aligned}
& \text { Dik }: \mathrm{n}=1800 \mathrm{rpm} \\
& N e=\frac{T \times n}{5252} \quad(\mathrm{Hp}) \\
& N e=\frac{210 \mathrm{Nm} \times 1800 \mathrm{rpm}}{5252} \\
& N e=71,97 \mathrm{Hp}
\end{aligned}
$$

c. Average piston speed (Vp)

$$
\begin{aligned}
& V p=\frac{2 \times L \times n}{60}(\mathrm{~m} / \mathrm{s}) \\
& V p=\frac{2 \times 0,0876 \mathrm{~m} \times 1800 \mathrm{rpm}}{60}(\mathrm{~m} / \mathrm{s}) \\
& V p=5,256 \mathrm{~m} / \mathrm{s}
\end{aligned}
$$

d. Average mechanical pressure (Pm)

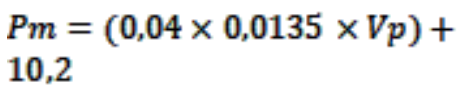

$\left(\mathrm{N} / \mathrm{m}^{2}\right)$

$P m=(0,04 \times 0,0135 \times$

$5,256)+10,2$

$\left(\mathrm{N} / \mathrm{m}^{2}\right)$ 


$$
P m=10,2028\left(\mathrm{~N} / \mathrm{m}^{2}\right)
$$

e. Average mechanical power $(\mathrm{Nm})$

$$
\begin{aligned}
& N m=\frac{P m \times V L \times Z \times n \times a}{450000}(\mathrm{Hp}) \\
& N m= \\
& \frac{10,2028 \mathrm{~N} / \mathrm{m}^{2} \times 445,1 \mathrm{~cm}^{5} \times 4 \times 1800 \mathrm{rpm} \times 2}{(\mathrm{Hp})} \quad 450000
\end{aligned}
$$

$$
N m=145,321 \mathrm{Hp}
$$

f. Indication Power (Ni)

$$
\begin{aligned}
& N i=N e+N m(\mathrm{Hp}) \\
& N i=71,97+145,321(\mathrm{Hp}) \\
& N i=167,482 \mathrm{Hp}
\end{aligned}
$$

g. Efficiency of thermal Engine (nth)

$$
\begin{aligned}
& \eta_{T h}=\frac{N e}{N i} \times 100 \% \\
& \eta_{T h}=\frac{71,97 \mathrm{Hp}}{167,482 \mathrm{Hp}} \times 100 \% \\
& \eta_{T h}=42,97 \%
\end{aligned}
$$

Results of the analysis of the performance of the Daihatsu Feroza engine

Table 4. Data from the calculation of engine performance with the fuel injection system.

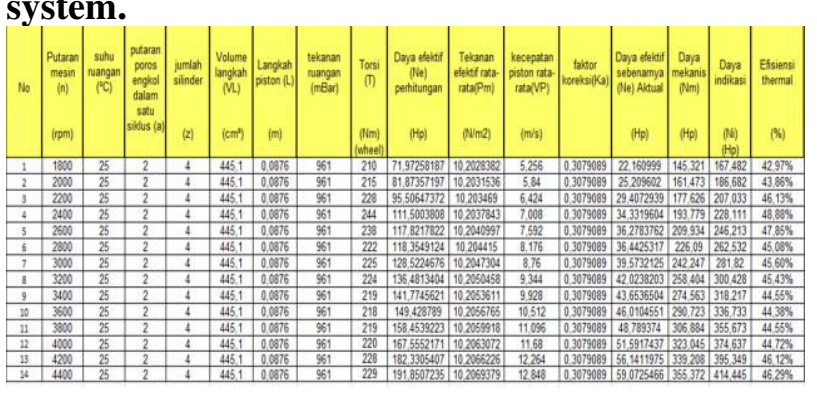

Table 5. Data from the calculation of engine performance with a conventional fuel system.

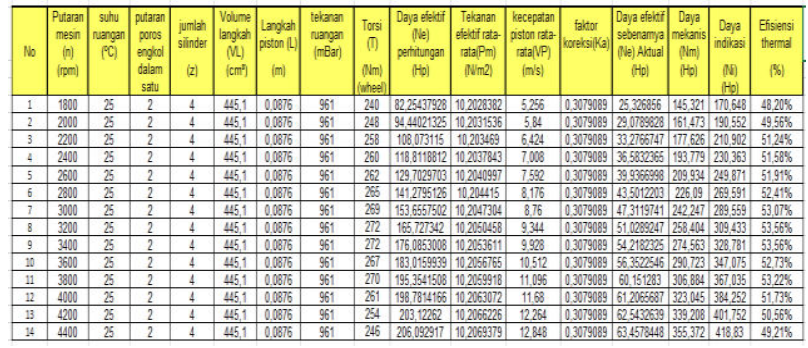

\section{Graph of Engine Performance with Conventional and Injection Fuel Systems}

The following is a graph of the rotation relationship to Torque (T) and Effective Power $(\mathrm{Ne})$.

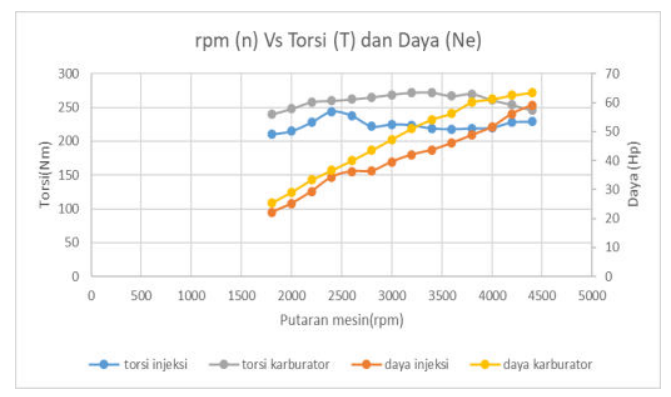

Figure 5.Graph of Relationship

Rotation (rpm) Torque (T) and Effective

Power (Ne).

Based on the graph above, it shows, if the motor rotation is increased, the general trend for torque will decrease, but the effective power graph will increase. This is in accordance with the formula above.

It can be seen that the higher the rotation (rpm), the torque obtained will increase. And the torque will decrease until the maximum engine speed. Due to the movement of the piston stroke cycle will be faster and so the motion of the suction valve will be faster, so that the fuel consumption into the combustion chamber will increase, so the sparks generated by the spark plug will be faster. At 2500 to $3000 \mathrm{rpm}$ the torque 
decreases due to the faster opening of the suction valve, the less fuel that enters the combustion chamber compared to when compared to ignition, but the higher the rotation, the effective power generated increases, at certain rotation will experience the maximum power will eventually decrease, because the higher the engine speed (rpm), the cycle moves quickly, and the power generated increases.

\section{Graph of Rotation Relationship to} Thermal Efficiency

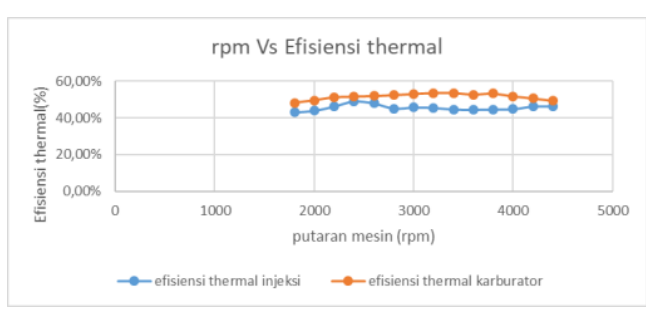

Figure 6. Graph of Circumference

\section{Relationship to thermal efficiency.}

Based on the graphic above, it can be seen that thermal efficiency tends to decrease if the engine speed (rpm) increases. This happens because the higher the engine speed, the piston speed will increase so that the combustion that occurs in the combustion chamber does not burn completely and the heat generated from combustion will decrease with increasing engine speed.

\section{CONCLUSION}

Based on the results of research and analysis of calculations regarding the performance of the Feroza Service Vehicle Modification Engine with the Fuel Injection System, the following conclusions can be drawn: a. In testing the performance of the Daihatsu Feroza engine with a conventional fuel system, it is known that the engine torque produced at the engine speed of $1800 \mathrm{rpm}$ is $240 \mathrm{Nm}$ and the resulting torque injection system is $210 \mathrm{Nm}$. The torque generated from the Daihatsu Feroza engine with a conventional system is greater than the torque generated by the injection system.

b. For the thermal efficiency produced by conventional systems at $1800 \mathrm{rpm}$ engine speed is $48.20 \%$ while the injection system is $42.97 \%$.

\section{REFERENCES}

E.KARYANTO Pedoman Reparasi Motor Bensin. Jakarta: CV.Pedoman Ilmu Jaya. M.KHOVAKH Motor Vehicle Engine..

Toyota Astra Motor.1989 Toyota Step 1, Jakarta: Toyota Astra Motor

Toyota Astra Motor.2000 Toyota Step 2 EFI, Jakarta: Toyota Astra Motor.

Astra Daihatsu Internasional,Jakarta : Astra Daihatsu Internasional.

Ir. Astu Pudjanarsa, MT, Prof.IR. Djati Nursuhud, MSME, 2006. Mesin Konversi Energi,Andi, Yogyakarta.

Buku Panduan Praktikum Motor Bakar. 2014. Malang: Laboratorium Motor Bakar Jurusan Teknik Mesin Universitas Brawijaya 